\title{
PRESCRIBING BEHAVIOR THROUGH DESCRIBING LIFE STAGES IN ALFONSO X'S SETENARIO
}

\author{
Robey Clark Patrick
}

The pair of manuscripts that give testimony to the Alfonsine work most commonly known as the Setenario has provoked lively debate over the past few decades. Kenneth H. Vanderford made the debate possible by producing a critical edition of the text in $1945,{ }^{1}$ but it was Jerry R. Craddock who breathed new life into "the problem of what place the Setenario occupies within the grouping of legislative works patronized by the Wise King." ${ }^{2}$ Craddock was the first to challenge the generally accepted theory that the Setenario was a preliminary draft to the magnum opus of the Siete Partidas by suggesting that it was more likely a later redaction of the great legal code begun in the years just before the death of the Wise King in $1284 .{ }^{3}$ More recently, José Luis Pérez López has argued that what we call the "Setenario" should be regarded as a fragment of the "authentic Setenario," the Siete Partidas, and that to refer to the text that is currently named Setenario "we shall name [it] Setenario Toledo-El Escorial (Setenario TE), since these two cities are where the two medieval manuscripts that contain the work are found."

Despite this renewed interest in the life and death of the Setenario, however, little ink has been spilt on analyzing the literary values of the

\footnotetext{
${ }^{1}$ See Kenneth H. Vanderford, ed., Setenario (Buenos Aires: Instituto de Filología, 1945).

2 "el problema del lugar que ocupa el Setenario dentro del conjunto de los cuerpos legislativos patrocinados por el Rey Sabio." Jerry R. Craddock, "El Setenario: última e inconclusa refundición alfonsina de la primera Partida," Anuario de historia del derecho español 56 (1986): 441. All translations are my own.

${ }^{3}$ Craddock, El Setenario, 453-54. Inés Fernández-Ordóñez echoes Craddock's argument and supplies further evidence to the theory that Alfonso X, and his scriptorium, labored extensively to rewrite his largest works during the final years of his reign. See "El taller historiográfico alfonsí. La Estoria de España y la General estoria en el marco de las obras promovidas por Alfonso el Sabio," in El Scriptorium alfonsí: de los Libros de Astrología a las "Cantigas de Santa María," ed. J. Montoya and A. Rodríguez (Madrid: Fundación Universidad Complutense, 1999), 5.

4 “para distinguirlo del auténtico Setenario (el Libro de las leyes, las Siete Partidas) vamos a denominar Setenario Toledo-El Escorial (Setenario TE), por ser en estas dos ciudades donde se encuentran los dos manuscritos medievales que contienen la obra." José Luis Pérez López, "Los prólogos del Libro de las leyes y el fragmento llamado Setenario en la obra jurídica alfonsí," Revista de literatura medieval 14, no. 1 (2002): 125.
}

ENARRATIO 21 (2017)

COPYRIGHT AUTHOR (C 2018 
work itself outside of that done by Rafael Lapesa during the 1980s and, more recently, Fernando Gómez Redondo. As Lapesa has noted, the text of the Setenario

confounds whoever approaches its pages for the first time. Everything [about it] contributes to the sense of strangeness. The missing initial folios, an important lacuna at the end of law XI, and the fact that it appears to have been left unfinished, [all] make it difficult to recognize a plan in it. ${ }^{5}$

Yet, in spite of these challenges, both scholars have managed to locate subtle themes at play throughout the work, finding an overall cohesion to the fragmented and incomplete book of laws. The goal of this article is not to resolve the problems of the work's specific place in the Alfonsine corpus or to convince readers that it is more cohesive than we previously imagined, though the latter may happen. Rather I intend to focus on one specific subsection of Ley XI of the Setenario with the hope that by better understanding a small piece of the work, we may better understand more global traits of the Alfonsine corpus itself. By narrowing my focus to this hermetic passage, I will argue that the "seven ages of man" as presented in the Setenario employs internal strategies of repetition and patternbuilding that guide the reader to be able to accurately calculate the distinct ages it discusses, while outlining the divisions of the life-cycle based on Aristotelian, Ptolemaic, and Galenic theories. Finally, by analyzing the central stage of development within the context of the passage and Alfonso's cultural campaign, I will show that the Setenario presents a prescriptive activity that provides instruction on how men should live their lives, as opposed to being a descriptive passage about how men of thirteenth-century Castile are truly living. Furthermore, and by way of conclusion, I will suggest that the appropriation of scientific knowledge coming from Arabic is an act that conspicuously subjugates Andalusī culture to the needs of Alfonso X and the Alfonsine corpus. For this undertaking, I have chosen to look at the subsection of Ley XI that discusses the seven ages of man, a portion of the text that does not appear

\footnotetext{
5 “desconcierta a quien por primera vez se acerca a sus páginas. Todo contribuye a producir extrañeza. La falta de los primeros folios, una importante laguna al final de la ley XI y el haber quedado, al parecer, inacabado hacen que sea difícil reconocerle un plan." Rafael Lapesa, "Símbolos y palabras en el Setenario de Alfonso X," Nueva Revista de Filología Hispánica 29.2 (1980): 247. See also Fernando Gómez Redondo, Historia de la prosa medieval castellana, Vol. 1. (Madrid: Cátedra, 1998).
} 
in the Siete Partidas, and to the best of my knowledge is unique to the Setenario. ${ }^{6}$

Making sense of the passage on the "ssiete hedades del omne" ["seven ages of man"] in Ley XI of the Setenario is not a straightforward task. The chore of constructing the life-cycle model in the Setenario is further complicated, as Lapesa has told us, due to the unclear generic categorization of the work, the disjointed nature of the text, and the fact that no complete manuscript survives, all of which has lead scholars to conclude that the work was never finished. ${ }^{7}$ Nonetheless, even a cursory reading reveals that the work is unified through the themes of reason, nature, order, and the noble quality of the organizational number seven. ${ }^{8}$ The organization of the work is as follows: Leyes I-X describe Alfonso $\mathrm{X}$, Fernando III, and the recently conquered city of Seville based on the seven virtues and other praises. Some of these laws use the seven letters of their names as the inspiration while others simply conform selected categories to seven qualities, such as gifts from God, attributes of leadership, or tribulations that were overcome. Ley XI changes the focus

\footnotetext{
${ }^{6}$ In the introduction to the Siete Partidas, as shown by Pérez Lópes, the ages of man is mentioned as being divided in seven parts, but no elaboration of those seven ages follows the statement and the topic is abandoned ("Los prólogos," 131-32). I would like to thank Linde Brocato and Michael Allman Conrad for pointing me to the Libro de los juegos, in which Alfonso utilizes both the tetratic theory of Galen in the description of Four-Seasons Chess (see Sonja Musser Golladay, "Los libros de acedrex dados e tablas: Historical, Artistic and Metaphysical Dimensions of Alfonso X's Book of Games," Ph.D. diss., The University of Arizona, 2007, 1366-68) and Ptolomy's cosmic model that connects the seven planets (the Moon, Mercury, Venus, the Sun, Mars, Jupiter, and Saturn) to humans as different ages to explain the game Tablero de los escaques (see Golladay, 1374-78).

${ }^{7}$ Gómez Redondo discusses its fragmentary nature and attempts to explain that the work was never finished because Alfonso X began to work on the Espéculo (Historia, 304-30), while Jesús de Rodríguez-Velasco, in "La urgente presencia de Las Siete Partidas," La Corónica 38.2 (Spring 2010): 99, contends that it was meant to distill the most important aspects of the Primera Partida and summarize its contents as a final "autobiografía política." Also see Craddock's article "El Setenario," where he is one of the first to propose that the work pertains to one of Alfonso's last projects.

${ }^{8}$ Lapesa unifies the work through the complex relationship of the macro- and microcosms, and the harmonious unity of all existence through a Christian lens, arguing that "todas las semejanzas, paralelos y prefiguraciones que se entretejenen el Setenario giran en torno a la idea axial de que el ser y el acaecer del universe entero son simbólicos" ("All the similarities, parallels, and prefigurations that are interwoven in the Setenario revolve around the central idea that all existence and all events of the entire universe are symbolic"), 253. This sentiment is also echoed by Brocato, "Alfonso X's Libro de ajedrez e dados e tablas or Libro de los juegos Interrogating Convivencia" in Revisiting Convivencia in Medieval and Early Modern Iberia (Newark, Del.: Juan de la Cuesta, 2014), 321-22, and Golladay 1222-33, in their writing on the Libro de los juegos.
} 
of the text from the particular to the universal, explaining that the work is organized by reason and nature in accordance with the noble number seven. Ley XI is unfinished and cuts off at the start of the fourth subdivision, "rrazón." The remaining Leyes, XII-CVIII, are less rigidly structured compared to I-XI yet are still recognizably organized around the theme of sevens. Within Ley XI the fragment in question occupies the final topic under "natura" before the subsequent subdivision of "ssabiduría" and a discussion of the seven arts. Although this Ley is unfinished (cutting off at the start of the fourth subdivision, "rrazón"), the portion of the ages of man is fortunately complete and so are all the subdivisions of Ley XI that surround and include it: entendimiento [knowledge], which precedes it; natura [nature], of which it is the final part; and sabiduría [wisdom], which follows it. ${ }^{9}$

Despite the Setenario's incomplete and fragmentary presentation, its description of the seven ages of man is complete and is organized in such a cohesive manner that this subsection of Ley XI should be considered a final version of the text itself, even if the work as a whole is not a final version. When approached as a cohesive unit, one can observe that the section of the ages of man follows a particular pattern and symmetry that permit its reader to chart the ages, but only once the reader submits her reading to the cultural campaign of the Wise King. Following the structure of the entire work, the life of a man is also divided into seven parts, or ages: ninnez (infancy), moçedat (childhood), mançebía (youth), omne conplido/con sseso (complete man/wise man), flaqueza (enfeeblement), veiedat (old age), and ffallesçimiento (demise, Vanderford 28). First I wish to point out the symmetry of the ages, which I contend is based on the Aristotelian arc found in the philosopher's proposal of three ages in which adulthood [manhood] is placed at the pinacle (see Fig. 1). ${ }^{10}$

\footnotetext{
${ }^{9}$ All quotations for the text of the Setenario come from Kenneth H.Vanderford's critical edition, unless stated otherwise. The two surviving manuscripts of the Setenario are San Lorenzo de El Escorial manuscript P.II.20 and Biblioteca Capitular de Toledo manuscript 43-20.

${ }^{10} \mathrm{~J}$. A. Burrow discusses Aristotle's belief that all life, including human, progresses in three stages: augmentum, status, and decrementum (5-10). Elizabeth Sears, in The Ages of Man: Medieval Interpretations of the Life Cycle (Princeton: Princeton University Press, 1986) explains: "The Pythagoreans, Aristotle records, seeing that the triad $(1,2,3)$ had a beginning, a middle, and an end, believed it to represent a whole. Working on the same assumption, Aristotle himself described the whole of life in three stages, phases in which
} 


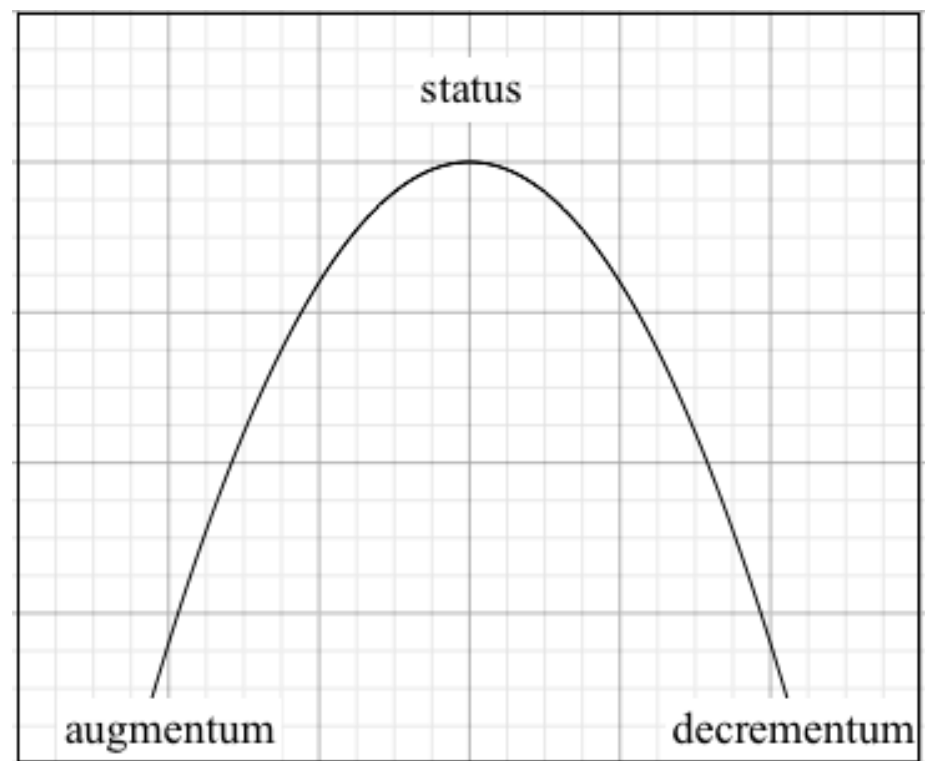

Fig. 1 The three life stages, based on Aristotle

The first and seventh ages are described inversely, as are the second and sixth, and the third and fifth, so that ninnez lasts "mientre el ninno non ssabe nin puede comer, e mama" (while the babe has no knowledge and cannot eat, and suckles) just as ffallesçimiento is when the subject returns to "sser commo ninno en su manera, de guisa que non cobdiçia ssinon comer e auer plazer" (be a child in his manner, in that he desires nothing but to eat and have pleasure, 28-29). Similarly, mançebía is when he enters "en edat que podría casar e auer fijos" (in the age that he is able to marry and have children) and in which he continues "creçiendo en su vida" (growing in his life), whereas its inverse, flaqueza, is when he arrives to "veiedat e le enffraqueçen los mienbros e va perdiendo la ffuerça que ssuele auer" (old age and his limbs weaken and he progressively loses the strength he once had, 29). Given the sexual focus on the youth's development of being eligible for marriage and capable of having children "en edat que podría ... aver fijos" (in the age that he is able ... to have children, emphasis my own), it is also logical to assume

adulthood was understood to be a mean between the extremes of high-spirited youth and subdued old age" (90). 
that weakening "mienbros" (literally, "members") and a loss of "la ffuerça" is an allusion to the aging man's physical inability to "aver fijos," or impotency.

While descriptions of physical change reinforce the inverse relationships and justify the placement of the topic within the subdivision of "natura," another unifying subject matter of the section is learning and knowledge, or ssabiduría. In the geriatric age of ffallesçimiento, for example, "va enfflaqueçiendo la natura e pierde el ssentido" (his nature continues weakening and he loses his senses, 29, my emphasis) connecting a lack of awareness to the return to infancy, the age marked by knowing naught/not. The crux of moçedat and veiedat as ages linked to the passing of sabiduría is even more pronounced, as moçedat is when he "aprende las cosas, quáles sson en ssí e cómmo han nonbre" (learns things, what they are in themselves and what they are named) and veiedat is not only when this learning is complete- "ha visto e prouado todas las cosas e las connosçe çiertamiente, quáles sson e cómmo deue obrar dellas" (he has seen and tried all things and he accurately knows them, how they are and how one should manipulate them) - but when he also is wise and can "mostrar a otro" (show/teach someone else) (28-29). In short, the mozo is defined as occupying an age for receiving knowledge while the viejo as occupying one for dissemenating it. Buttressing the pattern of mixed descriptions, some physical (natura) and others educational (ssabiduría) for each age, is the double-age of adulthood, centrally located and for which there are two terms in the text: the omne conplido (complete man) and the omne con sseso (wise man or man with sense). The arc is thus symmetrical with regards to the topics treated on either side of the central point (midlife), and each age corresponds inversely with the one on the opposing side (see Fig. 2). Now we are prepared to look at the transitions that occur when we progress from one stage to the next.

Based on each category, it can be seen that specific numerical age does not directly determine one's stage in life, but rather a preference is given to the description of the individual's development. For example, while the age at which one actually marries and has children can vary widely, once a youth is physically able to marry and have children he has entered mançebía. The repeated use of "quando" (when) and "ffasta que" (until) by the author, however, does not actually describe a space of transition between ages, but rather marks the moment when the next age 
eclipses the preceding one. Each subsequent age always cuts short the previous one, signifying that what may initially appear to be concluding limits in the section do not actually mark the span of a given age, but rather mark the moment at which it is impossible or inconceivable that the subsequent phase has not already eclipsed the previous one.

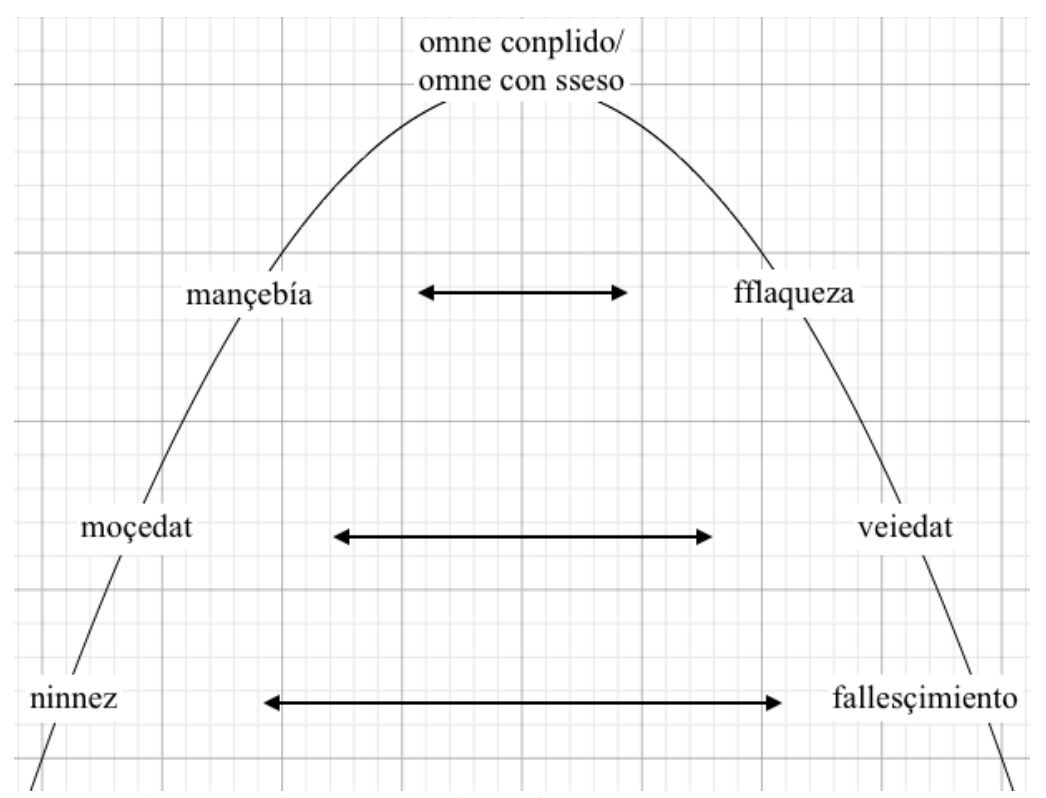

Fig. 2 The seven life stages, based on Ptolemy

Ninnez, while characterized by breastfeeding and not knowing how to eat (in contrast to drinking breastmilk), is defined by a lack of consciousness which is eclipsed at the moment the infant begins to be "moço e aprende las cosas, quáles sson en ssí e cómmo han nonbre" (a boy and learns things, what they are in themselves and what they are named). This definition of moçedat is applied to a child who has begun to use language, not just in the identification of objects, but specifically in the ability to correctly name the things in the world around him. Similarly, mançebía eclipses moçedat at the time the child "entra en edat que podría casar e auer fijos" (enters into the age that he is able to marry and have children). While mançebía extends through a nebulous time "de que ua creçiendo en su vida ffasta que llega a los quarenta annos e es omne 
conplido e a toda ssu ffuerça que deue auer" (during which he grows in his life until he arrives at forty years and is [a] complete man and has all [the] strength that he should have), the description of being an omne conplido also will cut short mançebía. The shift must occur before age forty, because one is only mançebo until ("ffasta que") "es omne conplido" (he is [a] complete man) and until "[h]a toda ssu ffuerza que deue auer" (he has all [the] strength that he should have), meaning that complete physical development and full strength are also items that will independently signal that one is no longer a mançebo. Regardless of these other factors of development, no one can be forty and be described as a mançebo, just as once one marries (or has a child), one cannot be a mozo. Likewise, as weak and as feeble as a man may become, veiedat does not enter ffallesçimiento until he loses "el ssentido e torna a sser commo ninno" ([his] sense[s] and returns to be as [a] babe). The pattern of eclipsing definitions is the guiding rule for how to understand the Setenario's divisions for the stages of life.

If the symmetrical properties correspond exactly, as I propose they do, then we can use the numerical figures provided in the text to calculate the range of each age quite precisely. Furthermore, misinterpretation of the text would also readily become apparent. For example, if mançebía extends to age 40, a conservative twenty-six years if we start mançebía at age 14, and being an omne con sseso is a twenty-year period from 40 to 60 , then fflaqueza should span another twenty-six years (age 86), veiedat another ten (age 96), and ffallesçimiento should occupy another four years before death at age 100. This does not agree with biological evidence of the human life-span, past or present, or the textual evidence regarding the imagined life-span during this period. ${ }^{11}$ However, if the

\footnotetext{
${ }^{11}$ Regarding the consistency of life expectancy in human populations of all times (contrasted specifically with that of chimpanzees), see Kristen Hawkes' article, "Human Longevity: The Grandmother Effect" (Nature 428.6979 [2004]: 128-29). For a discussion on recent changes in life expectancy and the history of theories on human longevity, see S. Jay Olshansky, Bruce A. Carnes, and Aline Désesquelles in "Prospects for Human Longevity" (Science 291.5508 [2001]: 1491-92), who contend that intrinsic ("internal") causes of death impose a limit to longevity. Jim Oeppen and James W. Vaupel, in contrast, in "Broken Limits to Life Expectancy" (Science 296.5570 [2002]: 1029-31) contend that life expectancy will continue to break limits as science progresses. Fundamental to the debate is that the calculation of "life expectancy" includes the infant mortality rate of a given society at a specific time, or the "mean age of death," and the general consensus that the twentieth century saw a jump in life expectancy due to the decrease of the infant mortality rate. Olshansky, et al., contend that this was a one-time bump, whereas Oeppen and Vaupel point to advances made since the 1950s to elderly care in first-world nations as evidence that science is still driving up life expectancy past "scientific" predictions of life
} 
numbers in the text correspond to the middle of the ages of omne con sseso and fflaqueza, not the endpoints, then an exceptionally accurate depiction of the stages of life emerges from the Setenario: ninnez from birth to about age 4 (four years), moçedat until about age 12 (eight years), mançebía until around 28 (sixteen years), omne con sseso until about 52 (twenty-four years, with the age of 40 centered at twelve years after mançebía ends and twelve years before fflaqueza begins), fflaqueza until age 68 (eight years from 52 to the marked age of 60, and another eight years before veiedat begins at 68 , a total of sixteen years), veiedat until age 76 (eight years), and ffallesçimiento another four years until death at age $80 .{ }^{12}$ Not only does this timeline for life make sense concerning the symmetry in the text, as well as corresponding with the recognized changes in human development and aging, it also coincides with other contemporary theories of the ages of man, primarily the fourstage life-cycle based on Galenic medicine. ${ }^{13}$

As mentioned above, I contend that the description follows an arc based on the Aristotelian model of three ages. The material preceding the passage in question on the nature of things is based on Aristotelian, and pseudo-Aristotelian, thought, which should guide the reader towards this

expectancy limits. For the current article, the reader should understand that the low age of life expectancy during the Middle Ages is primarily due to high rates of infant (through prepubescent) mortality and that this figure does not reflect the life-span of medievals. I would like to thank Trent Trombley for references and his insight on current anthropological ideas about the human life-span, particularly regarding the misconception that life expectancy correlated with life stages during the Middle Ages (and elsewhere).

${ }^{12}$ I will discuss the importance of these specific numbers below, but it should be observed that if 40 years is the mid-point of a symmetrical arc, then regardless of the division of each life stage on either side, the model always concludes with a life expectancy of 80 years.

${ }^{13}$ Michael E. Goodich discusses life expectancy during the late-thirteenth and earlyfourteenth centuries in the introduction of his work From Birth to Old Age: The Human Life Cycle in Medieval Thought, 1250-1350 (Lanham, MD: University Press of America,1989), stating that "[e]vidence drawn from the privileged classes indicates large numbers of persons surviving into their sixties and seventies" (7). A more exhaustive treatment of the topic can be found in Youngs' book, The Life Cycle in Western Europe, c.1300-c.1500 (Manchester, UK: Manchester University Press, 2006), particularly in the chapter "Age and Life Expectancy" (11-38). See Isabelle Cochelin's "Introduction" to the book Medieval Life Cycles: Continuity and Change (Turnhout: Brepols, 2013, 1-54) for an overview of lifecycle theories circulating prior to the thirteenth century. For a discussion on Galen and humoral and tetratic theory, particularly with regards to his expansion of the theory to include the four elements, see Sears, The Ages of Man, 14. 
classical model. ${ }^{14}$ For example, although the author of the Setenario divides the topic of nature into seven parts in order to continue the leitmotif of the project, the introduction to the section on "natura" describes the threefold sequence of life along Aristotle's lines of augmentum, status, and decrementum, stating, "Natura es la ssegunda parte de este setenario, que muestra las cosas ónde nasçen e cómmo e en qué guise obran por ssipse o vnas con otras, e otrosí en qué manera sse desffazen" (Nature is the second part of this setenario, which shows things, where they are born and how and in which ways they function in themselves or with other [things], and in what way they are undone, 26). At the same time, Latinate cultures only recently [re]-acquired Aristotle (as well as Ptolemy and Galen) by way of the various translation projects of the twelfth and thirteenth centuries, and scholars familiar with the new sciences also knew that their immediate sources were primarily circulated in Arabic. ${ }^{15}$ Concerning the path of inheritance of Greek material for Alfonso X, Francisco Márquez Villanueva reminds us that "lo mismo que para Federico II, el mayor legado de Grecia le llegaba sobre todo a través de intermedios árabes" (just as for Frederick II, the largest inheritance from Greece arrived to him, above all, by way of Arab intermediaries). ${ }^{16}$ The arc, therefore, while created by the Greek Aristotle, was simultaneously a cultural and intellectual relic of Arabic scholarship, regardless of whether or not the text explicitly recognizes its intellectual history.

The seven-fold division of the ages is the most clearly present classical model found in the passage, and in the whole work, and is closely associated with Ptolemy and astrology. Starting in the twelfth

\footnotetext{
${ }^{14}$ H. Salvador Martínez contends in his biography, Alfonso X, el Sabio. Una biografía (Madrid: Ediciones Polifemo, 2003), that "[m]ateria y forma son dos de las cuatro causas aristotélicas entorno a las cuales Alfonso, como gran admirador que era del estagirita, estructura no sólo el Setenario y las Siete Partidas, sino también sus dos grandes compilaciones históricas" ("matter and form are two of the four Aristotelian "causes" around which Alfonso, as a great admirer of the Stagirite, structures not only the Setenario and Siete Partidas, but also his two great historical compilations [the Estoria de España and the General Estoria]," 301).

${ }^{15}$ Şā'idal-Andalusī (1029-1070 CE) describes the intellectual movement of Aristotle, Galen, and Ptolemy from Greece to al-Andalus in his eleventh-century work Tabaqāt al'Umam (Book of the Categories of Nations), in which he also divides the original nations of the world into seven. See Sema'an I. Salem and Alok Kumar (trans. and ed.), Science in the Medieval World: "Book of the Categories of Nations" by Şã id al Andalusī (Austin: University of Texas Press, 1991), 3-5.

${ }^{16}$ Francisco Márquez Villanueva, El concepto cultural alfonsí: edición revisada y aumentada (Barcelona: Ediciones Bellaterra, 2004), p. 69.
} 
century, Ptolemy and his commentators were being translated into Latin from Arabic sources, and with these texts came the emerging seven-stage life-cycle, which was based on celestial sympathy. According to Sears, "as astrological thought gained ground in the later Middle Ages, the theory of planetary influence on the seven ages of man became a commonplace." ${ }^{17}$ To further emphasize the astrological underpinnings of the life-cycle divided into sevenths, I rely on J. A. Burrow's assertion that "it was the revival of astrology in this period [when Plato of Tivoli translated Ptolomy's Tetrabiblios from an Arabic source into Latin in the early twelfth century] that was chiefly responsible for establishing the scheme of the seven ages as a scientific hypothesis which could stand alongside that of the four ages. ${ }^{18}$ Starting with the Moon and moving outwards through the Heavens from Earth's central position, each celestial body was paired with a stage in human development: Moon/infancy, Mercury/childhood, Venus/youth, Mars/adulthood, Sun/late adulthood, Jupiter/old age, and Saturn/perishment and death. One could suggest that Alfonso, or his team, was not familiar with these ideas as a way of explaining the lack of astrological material in this section, but one familiar with the Setenario knows that a marriage of astrological thinking with Christian theology occurs later in the work, when Alfonso discusses the seven planets in heavenly order through Biblical exegesis. ${ }^{19}$ Without supplying all of the ways that we know that Alfonso and his team were well aware of ancient and cutting-edge discourses on astrology, my point is that this material is not missing from the life-cycle here, rather, it is suppressed. ${ }^{20}$

The text has similarly subtle associations with Galenic medicine through the particular numbers used as dividing points in the passage

\footnotetext{
${ }^{17}$ Sears, Ages of Man: Medieval Interpretations, 53.

${ }^{18}$ Burrow, Ages of Man: A Study, 40.

${ }^{19}$ Vanderford, Setenario, 81

${ }^{20}$ Alfonso X's interest in astrology is too large of a topic to discuss in this paper. In place of an exhaustive bibliography, I recommend starting with Francisco Márquez Villanueva's El concepto cultural alfonsí (Barcelona: Ediciones Bellaterra, 2004), specifically the chapter "Astrología, magía y adivinación" (203-10), Simon R. Doubleday's The Wise King: A Christian Prince, Muslim Spain, and the Birth of the Renaissance (New York: Basic Books, 2015), particularly the chapter "Stargazers" (53-79), and Norman Roth's contribution, "Jewish Collaborators in Alfonso's Scientific Works" (59-71), to Robert I. Burns (ed.) collection of essays, Emperor of Culture: Alfonso X the Learned of Castile and His Thirteenth-Century Renaissance (Philadelphia: University of Pennsylvania Press, 1990).
} 
(see Fig. 3) ${ }^{21}$ Forty and sixty when placed in the middle of their respective ages, as I suggest, permit a secondary arc of development in concordance with medical science based on the four humors. Twenty, Forty, Sixty, Eighty — each marks the end of one quarter of the life-cycle, with Forty splitting the center age of Adulthood into "omne conplido" and "omne con sesso." Later in the Setenario, the four elements (Earth, Water, Air, and Fire) are discussed in the section that precedes the seven planets, which suggests that Alfonso and his team were similarly familiar with the paradigm of the four-fold life-cycle. ${ }^{22}$

\section{Tetratic Theory (Based on Galen)}

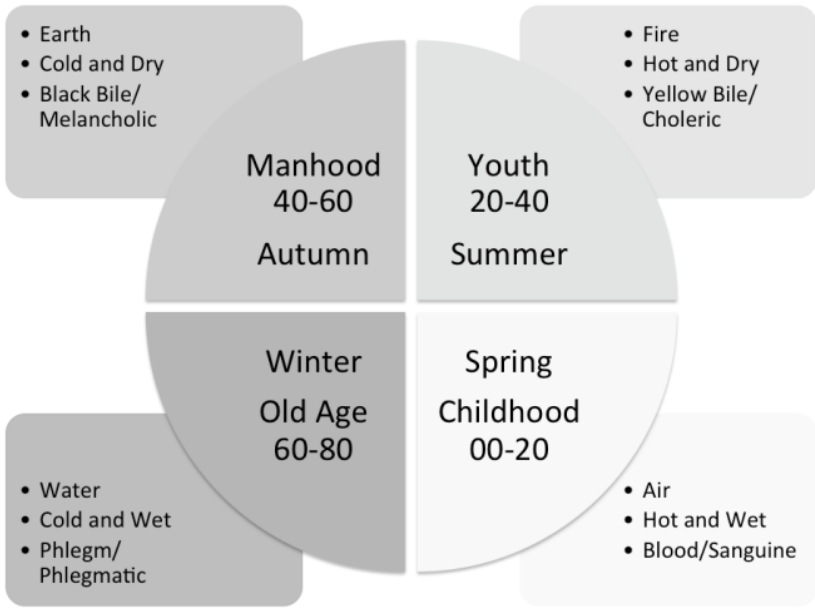

Fig. 3 The four life stages, based on Galen.

\footnotetext{
${ }^{21}$ Regarding the physiological theory of the four ages of man, Burrow states: "The greatest of these later writers was the physician Galen (second century CE). In several works associated with his name, one finds the parallels between ages, seasons, and humours plainly stated, always in terms of the four qualities" (15).

${ }^{22}$ Later versions of Galenic medicine contain the four elements as part of this paradigm (Burrow 15, n. 25). For another example of Alfonso X's use of Galenic medicine in the Libro de los juegos, see Golladay (particularly sections 1.5 and 3.2.4).
} 
This instance in the Setenario provides further evidence for what Sears has called a "kinship between medical and astrological thought with regard to the ages of man," in that both models exist harmoniously, yet neither dominates as the sole guide to interpretation. ${ }^{23}$ The overlapping of medical and astrological information is also apparent in another mid-thirteenth century text, the Regimen sanitatis Salternitani / De conservation sanitatis, which also divides the ages of man into seven: infans, puer, adolescens, juvenis, vir, senex, and decrepitas; and which Burrow calls "the single most widely distributed source of medical speculation concerning the ages of man and the means of extending life." ${ }^{24}$ Further elaboration of medical or tetratic theories in Ley XI, however, do not appear. Similarly to the astrological material, Alfonso and his team have suppressed the direct discussion of medical discourses while simultaneously relying on that discipline's authority regarding the topic of the life stages.

The combination of the life-cycle theories founded in Aristotelian, Galenic, and Ptolomaic philosophy, however, is not a seamless fabric of texts in the Setenario. Despite the author's desire to conform the subsection on the ages of man as a whole to the sevenfold leitmotif of the project, the inclusion of Galen's tetratic theory creates an obstacle to the Aristotelian tripartite theory that all life can be divided into the stages of augmentum, status, and decrementum. ${ }^{25}$ This conflict is resolved in the Setenario by introducing the double-age of the omne conplido / omne con sseso at the top of the arc where Aristotle places status. ${ }^{26}$

A peculiar aspect of this section of the passage is that it is the only stage that defies a strict linguistic nomenclature. In the pictorial representation within the manuscript, the stage is clearly defined as "omne con sseso," with the title occupying the fourth circle of the seven

\footnotetext{
${ }^{23}$ Sears, Ages of Man: Medieval Interpretations, 48.

${ }^{24}$ Burrow, Ages of Man: A Study, 37. I would like to call attention to the fluid use of juvenis and vir, both of which appear to be connected to adulthood/midlife, and the distinction of adolescens and juvenis made in this popular medical text. Specifically, I want to point out that juvenis is associated with the Sun, and not Venus, and that vir is connected to Mars, and not the Sun. See note 28 below for more on the topic of iuuentus.

${ }^{25}$ All odd-numbered theories on the life stages can neatly fit into the Aristotelian concept, but even-numbered theories must find a way to explain the lack of a central stage of status.

${ }^{26}$ Dante Alighieri, a near-contemporary of Alfonso X, also uses a semi-circular arc to represent Aristotle's three ages of man with adulthood at the pinnacle (Burrow, Ages of Man: A Study, 7).
} 
ages of man just like the other, better defined ages. Nonetheless, within the passage itself the first definition used to distinguish it from the preceding stage of mançebía is the term omne conplido:

Mançebo es de que ua creçiendo en su vida ffasta que llega a los quarenta annos e es omne conplido e a toda ssu ffuerça que deue auer. Omne con sseso es quando ua ssaliendo desta ssazón e llega a los ssesenta annos e comiença a entrar en flaquedat. (29)

[A youth is he who grows in his life until he arrives at 40 years and is a complete man and he has all the strength that he should have. He is a wise man when he starts leaving this proper condition and he arrives at 60 years and begins to enter enfeeblement.]

The similar grammatical structure of the two sentences that encompass the whole of the "omne conplido / omne con sseso" double-age contains no internal indicators regarding the appropriate name of the stage, leaving the introductory titles at the start of the subsection as the only guiding rule for why one would call the stage "omne con sseso." Furthermore, the two limited descriptions of this age define "middle age" as an ideal state, one of a fully developed individual who has not yet begun the process of "weakening" (the characteristic of fflaqueza). As Youngs explains in her article on adulthood,

Being at the midpoint of life meant occupying the central stage in life. It was the point where the body was in balance: it had all the advantages of youth and old age-physical excellence and a rational outlook respectively - but none of their excesses and defects. Midlife, for example, did not suffer the humoural imbalances of fickle youth, which was enslaved to passion and turmoil. The sense of balance was heavily influenced by Aristotle, who promoted the idea of a person's ideal moral mean. For him, 'middle age' was the 'perfect age' of life, and medieval writers followed his lead. ${ }^{27}$

The lack of further explanations in the passage about the qualities of midlife, therefore, communicates the heavy reliance of the author on the Aristotelian theory of balance (which values this stage above the rest), as

${ }^{27}$ Deborah Youngs, "Adulthood in Medieval Europe: The Prime of Life or Midlife Crisis?" In Medieval Life Cycles, edited by Isabelle Cochelin and Karen Smyth (Turnhout, Belgium: Brepols, 2013), 244. 
the simple act of dubbing the man "conplido" clearly corresponds to the idea of status in the Aristotelian tradition. In contrast to the declared title of the segment, "omne con sseso," the transition from mancebia to midlife is designed to first allude to Aristotle's tripartite theory of the life-cycle.

While the first description directs the reader to consider the perfect stage of status, the second one limits the praise of the omne conplido to apply only to those who are also "con sseso" (with sense/with prudence). The linguistic splitting of the age into the descriptors omne conplido and omne con sseso functions as a crossroads for the disparate life stage models employed by this passage of the Setenario, allowing the reader to see more clearly the various disciplinary theories of the ages of man, both divided and harmonized. By the subsection's very nature of describing a sevenfold life-cycle, the Ptolomaic theory is always present. Midlife portrayed as the omne conplido similarly connects the passage to Aristotelian balance and the tripartite theory. The second aspect of the omne con sseso, nontheless, allows for the Galenic theory of the tretratic theory to become more visible as it suggests a break in the middle, significantly at age 40 , where the first half of life is seen as augmentum towards its pinnacle at a balanced 40 and the second half as decrementum towards death at 80 . Once divided in halves, the tetratic model emerges, with two meaningful sets of quarters, one numerical and one seasonal/humoral. As seen above, numerically we already have the stated midpoint of fflaqueza at 60 and the inverse midpoint of mançebia consequently at 20 , resulting in the quarters of $0-20,20-40,40-60$, and 60-80. According to the seasons and humors, ninnez and moçedat get grouped under the ideas of pueritia and Spring/blood, mançebía and omne conplido correspond to iuuentus and Summer/cholera, omne con sseso and fflaqueza fall under vir and Autumn/meloncholia, and veiedat and ffallesçimiento are associated with senectus and Winter/phlegm. ${ }^{28}$

\footnotetext{
${ }^{28}$ Despite the etymological connection between the Latin term iuuentus and "youth" ("juventud"), life-cycle narratives of the Middle Ages suggest a more advanced age for the term "youth" than we use today, as seen by the interchangeable use of iuuenis and vir in many texts, as shown in Cochelin, "Introduction," 4-5. An early study that began the process of questioning the meaning of iuuentus is that of Georges Duby, "Dans la France du Nord-Ouest au XIIème siècle: les 'jeunes' dans la société aristocratique," Annales ESC 5 (Sept.-Oct 1964): 835-46. For a study discussing texts from Spain, see Susana M. Belmartino's article 'Estructura de la familia y 'Edades sociales' en la aristocracia de León y Castilla según las fuentes literarias e historiográficas (siglos X-XIII)," Cuadernos de historia de España 47-48 (1968): 256-328.
} 
The implementation of a double age therefore functions, on one hand, to reveal the various life-cycle theories on which the passage depends in order to support its structure and lend it authority while, on the other hand, to harmonize these same theories under one central age as first declared in the subsection titles (omne con sseso) while conforming the whole subsection to the pattern of sevens.

The pinnacle of the Aristotelian arc, the central sphere of the Ptolomaic macroverse, and the season of the life-cycle where humors are balanced according to Galen all coincide and are harmonized during this double age of midlife in the Setenario, and then subjugated to its title, the omne con sseso. As the name suggests, along with the choice to declare the stage as that of the omne con sseso over the omne conplido, the topic of knowledge comes to dominate the very definition of being conplido. "Sseso" (sense/wisdom/knowledge), if not anticipated prior to the double-stage, is explicitly declared as the concept that correctly guides the reader in how to interpret the whole passage. The reader, once he submits his interpretation to the authorities conjured by the structure and division of the life stages, reorients his understanding of the ages of man in concordance with the topic of sseso, which is reinforced through progressive and inverted descriptions that are unified under the balanced, central stage of the omne con sseso. Physical (three), medical (four), and astronomical (seven) sciences become harmonized under the exaltation of the omne con sseso and through the perfect number seven, which is joined to the spiritual sevens of the seven virtues and the seven sacraments. ${ }^{29}$

\footnotetext{
${ }^{29}$ After the Siete Partidas, the second-most celebrated Castilian work that builds on the theme of sevens is Pablo de Santa María's Las siete edades del mundo (1404/1430), which discusses translatio imperii of seven empires over the course of seven ages of human civilization. It is not unlike Şā'idal-Andalusī's eleventh-century text, Tabaqāt al-'Umam (Book of the Categories of Nations), except that Pablo de Santa María's work is in octava real and culminates in the Kingdom of Castile under the Trastámaran line of kings, as opposed to the Islamic civilization in al-Andalus. Alan Deyermond in his article "Written by the Victors: Technique and Ideology in Official Historiography in Verse in LateMedieval Spain," The Medieval Chronicle VI, edited by Erik Kooper (Amsterdam \& New York: Rodopi, 2009), 59-89, and Juan Carlos Conde in his article "Las siete edades del mundo de Pablo de Santa María y su significación ideológica," Modelos intelectuales, nuevos textos y nuevos lectores en el siglo XV, directed by Pedro M. Cátedra (Salamanca, Spain: Seminario de Estudios Medievales y Renacentistas [SEMYR], 2012), 61-95, have both brought to light the subtler political and ideological aspects of Pedro de Santa María's work.
} 
The union of the numerous sources of authority has the effect of naturalizing the seven-fold division of the life stages of man. But the man who is the protagonist of Alfonso's life stages is first and foremost social, not physical, biological, or cosmic. Alfonso is not describing how man is, but rather prescribing how man ought to be. The rex sapiens is outlining his vision of the homo sapiens, but instead of conveying the material as subjective he deploys his vision through the authority of various traditions that turn it into objective truth. The passage from the Setenario performs a prescriptive and naturalizing act, as the engagement with learning as recipient, reservoir, or disseminator is linked to specific life stages so that the pursuit of wisdom is both natural to man at every stage of life and at the same time a determining factor concerning the way that one should be treated. In this light, the hortatory statement that "tales vieios commo éstos deuen sser enuergonçados e onrrados" (old men such as these ought to be respected and honored) is not so much a lament about how those in their golden years are not being treated with the respect that they deserve, as an attempt to communicate what accomplishments make one deserving of respect and honor during one's vejez (29) ${ }^{30}$ To not pursue wisdom is contrary to the nature of man, whereas wisdom's pursuit is both natural and praiseworthy. Following the practice already established in other works of the Alfonsine Corpus, the Setenario is similarly prescriptive rather than descriptive. ${ }^{31}$

Within the context of Alfonso's reign, the life-cycle passage similarly naturalizes the cultural campaign of the Wise King while also suggesting that detractors of the campaign are not just opposed to scholarly activities but are somehow expressing ideas that go contrary to

\footnotetext{
${ }^{30}$ It may be interesting to look at this passage in light of J. L. Austin's theories on "perlocutionary speech acts" as found in his collected lectures, How to Do Things with Words (London: Oxford University Press, 1962), particularly lectures VIII through XII.

${ }^{31}$ Gómez Redondo affirms that "en el Setenario se encuentra ya esbozado el discurso prosístico en el que se asentarán las obras mayores del Rey Sabio (la indagación etimológica, el didactismo expositivo, la configuración de un espacio textual rico en perspectivas y en organización narrativa)"("in the Setenario one finds the arguments in prose, in which the major works of the Wise King will be based [etymological inquiry, expositive didacticism, and the configuration of a textual space that is rich in perspectives and narrative organization], already sketched," 304). In addition to Goméz Redondo's study, Márquez Vilanueva's El concepto cultural alfonsí is indispensable for understanding current scholarship on the Alfonsine court and corpus, as is Burns' (ed.) Emperor of Culture. In the realm of historiography, one should look to Anthony J. Cárdenas and his article "The Myth of Hercules in the Works of Alfonso X: Narration in the Estoria de España and in the General estoria, "Bulletin of Hispanic Studies 74, no. 1 (January 1997): 5-20, which discusses the role the narrator plays in advancing Alfonso's goals.
} 
man's nature. Opponents to the reforms that Alfonso seeks can justifiably be stripped of respect and honor in accordance with the text, as they would not be living up to the demands of their age. In addition, Alfonso positions himself as the rex sapiens who is the primary example of the homo sapiens as defined in the passage. As seen in other texts of wisdom literature produced under Alfonso X, the very products of the cultural campaign become the tools of justification for its continuation and the examples of its success. ${ }^{32}$

The proposed life-cycle as found in Ley XI of the Setenario unites wisdom from Arabic and Latin sources, harnessing the scientific paradigms from Aristotelian, Galenic, and Ptolemaic traditionstransmitted through sources understood as the rightful inheritance from Arabic - in order to advance the cultural goals of Alfonso X. ${ }^{33}$ Nonetheless, although the Setenario utilizes these various traditions, it was not translated from Latin, Arabic, or Hebrew, and is considered an original work from the reign of Alfonso $\mathrm{X}$ that was possibly begun under the command of Fernando III. ${ }^{34}$ Regardless of whether the father or the

\footnotetext{
${ }^{32}$ For more on the intimate connection between Alfonso X's politics and cultural campaign, see Márquez Villanueva, who states, "Su misma obra literaria no es sino culminación de un vasto proyecto de gobierno al que caracterizan tanto la claridad de objetivos como la tenacidad con que es llevado a la práctica" (His own literary corpus is nothing but the culmination of a vast government project that is characterized as much by its own directness of its goals as the tenacity with which it is put into practice, 25). In particular, the Castilian translation of the Calila e Dimna has generated interest in the way Alfonso $\mathrm{X}$ legitimated his cultural campaign through his patronage of literature. For example, Jessica Katherine Zeitler, "Intellectual Cartographic Spaces: Alfonso X, the Wise and the Foundation of the Studium Generale of Seville," (Ph.D. diss., University of Arizona, 2013), 195, asserts that: "The motivation behind the translation of this venerated work links to imperial ideology that legitimized their reign through the translation and incorporation of such knowledge into their collection." Similarly, Gómez Redondo, Historia, analyzes the aspects of Calila e Dimna that would interest Alfonso, and the distinct goals for reception between the two versions of the journey of Berzebuey, one a fragment of the work interpolated in the General Estoria and the other appearing as a chapter in the frame tale collection itself (181-87).

${ }^{33}$ For an example of translators' practices of recording the titles and authors of their Arabic sources, see C. S. F. Burnett's "A Group of Arabic-Latin Translators Working in Northern Spain in the Mid-12th Century," The Journal of the Royal Asiatic Society of Great Britain and Ireland 1 (1977): 62-108. For more on the intellectual inheritance from Arabic in general, see Charles Homer Haskins' book, The Renaissance of the Twelfth Century (Cambridge: Harvard University Press, 1927), and, in particular, chapter nine, "The Translators From Greek and Arabic" (278-302).

${ }^{34}$ Fernández-Ordóñez, "El taller historiográfico," supports the argument that Alfonso X, and not Fernando III, is responsible for the making of the Setenario, which she sees as part of Alfonso's second, revisionist phase in book making (107-10).
} 
son began the work, elements of the text are undeniably the fruits of Castile's great translation projects, which sought to make the intellectual inheritance of al-Andalus its own. The emergence of this Castilian production precedes Don Juan Manuel's most well-known work, the Libro del conde Lucanor, but perhaps equally embodies the idea of "cultural colonization" that David Wacks finds in the fourteenth-century frame tale collection. ${ }^{35}$ Many of Wacks' conclusions about the colonization of Andalusī culture found in the Conde Lucanor are applicable to earlier works, like the Setenario. For example, Wacks observes that "Juan Manuel's use of Andalusī narrative material (anecdotes and tales) [...] is meant to inject a bit of authority derived from the prestigious cultural legacy of al-Andalus." Unlike Juan Manuel, however, the king who ordered the making of the Setenario is not only "laying claim to the historical legacy of the al-Andalus colonized by his grandparents' generation," but he is also reminding contemporary readers of his own participation in the conquest of peninsular territory, implicitly through the philosophical traditions harnessed by those who work in his scriptorium and explicitly through the discussion of the conquest of Seville that precedes Ley XI (149). ${ }^{36}$

A better understanding of the passage of the Setenario in question is important for a number of reasons. First, it is another example of how Alfonso subjugates various disciplines and authorities in his works in order to support his cultural campaign, a campaign inextricably interwoven with Alfonso's desire to centralize juridical and political authority under the power of the crown. Scholars have argued that the "Arabized" qualities of Alfonso's court are a demonstration of Castilian

\footnotetext{
${ }^{35}$ David Wacks, Framing Iberia: Maqamat and Frametale Narratives in Medieval Spain, Medieval and Early Modern Iberian World, vol. 33 (Leiden and Boston: Brill, 2007), 131.

${ }^{36}$ Wacks, Framing Iberia, 149. Eloísa Palafox, in Las éticas del exemplum. Los Castigos del rey don Sancho IV, El Conde Lucanor y el Libro de buen amor (México, D.F.: Universidad Autónoma de México, 1998), describes a similar situation in Castigos de Sancho IV, produced by Alfonso's son, where the narrator, Sancho IV, invokes the recent conquest of the city of Tarifa within his compendio de castigos as a reminder of his participation in that reconquest (59). Gómez Redondo, Historia, discusses the political motivations behind Leyes I-X, which he considers nothing short of political propaganda for Alfonso X's court (307-15). Concerning Alfonso's imperial aspirations, James F. Burke, in "Alfonso X and the Structuring of Spanish History," Revista Canadiense de Estudios Hispánicos 9, no. 3, Spring 1985, argues, "If Alfonso is to be assimilated to the Imperial succession he would also have to have had a city worthy of him. The description of the newly conquered Seville in which Alfonso would take such an interest in the Setenario is certainly as florid and grandiloquent as anything done by Rodolphus" (468-69).
} 
hegemony over the culturally superior Islamic civilization that continued to challenge Christian dominance in the Mediterranean. By extension, the passage in the Setenario evokes the crown's previous successes in war in order to legitimize the centralization of royal authority. ${ }^{37}$ Second, it exemplifies how even the most seemingly straightforward passages of the corpus contain thick layers of explicit and implicit intertexts that should not be overlooked, and how Iberianists who do not classify themselves as "Arabists" would nevertheless benefit from being familiar with Andalusī cultural practices, such as the Islamic courtly tradition of $a d a b$ in literature, when interpreting works associated with the Alfonsine corpus. ${ }^{38}$ And, third, it raises questions for other descriptions of the lifecycle: To what degree are passages on the stages of life descriptive or prescriptive? How do life-cycle theories put learned authority to use? What systems of power are being legitimized or silenced through the decision to follow one life stage theory over another? I ask "to what degree" because I contend that to write about life stages is always both, just as these narratives are always making use of the authority of their sources in order to legitimize, or delegitimize, culturally specific discourses of some import to the author.

The passage in the Setenario provides scholars with a case of what I see to be a primarily rhetorical and prescriptive depiction of the lifecycle, or perhaps even intentionally prescriptive. ${ }^{39}$ The very social descriptions of each stage in the Setenario make the prescriptive quality of the passage easily recognizable, but the common practice within the genre of life-cycle narratives of connecting social roles and activities to specific ages should also be looked at as prescribing and naturalizing certain behaviors for certain members of society. For authors familiar with various theories, the choice to follow an Aristotelian, Galenic, Ptolomaic, or other model cannot be separated from the greater project within which the life-cycle narrative is contained. While the prescriptive effect of the passage here is not surprising for scholars of the Alfonsine

\footnotetext{
${ }^{37}$ See María Rosa Menocal, "To Create an Empire: Adab and the Invention of Castilian Culture," 195; Wacks, Framing Iberia, 96-103; and Zeitler, "Intellectual Cartographic Spaces," 193.

93. ${ }^{38}$ See Maribel Fierro, “Alfonso X 'The Wise': The Last Almohad Caliph?” 176, 186-

${ }^{39}$ While I am not depending on Austin (How to Do Things with Words) for my analysis, his lectures about "performative utterances" and "perlocutionary speech acts" may be helpful for considering how an ostensibly descriptive narrative, such as one describing the life-cycle, is also performing a variety of actions.
} 
corpus, it serves to remind us that all medieval depictions of the human life-cycle are not only descriptions of an ideal, but are also always a rhetorical strategy for attempting to normalize the behavior of specific members of society at different junctures in their lives.

In thirteenth-century Castile, respecting ssabiduría as the natural, highest pursuit of men legitimizes the intellectual projects of Alfonso X, and simultaneously reinforces his image and position as el rey sabio and el rey de los sabios. Alfonso, famous for keeping wise men around him and "old" for his physical age (as measured by his breadth and depth of knowledge), like tales vieios cómmo éstos (old men such as these) in his court also "deu[e] sser enuergonçad[o] e onrrad[o]" (ought to be respected and honored) for his ssabiduría. Men who wish to follow the natural course of aging, therefore, should likewise wish naturally to receive instruction from their intellectual superiors, which at this time is their natural king, Alfonso X. Just as Alfonso followed his (older and wiser) father, Fernando III, into battle to conquer Seville, so much the more should the nobles follow Alfonso on his endeavors, he who has surpassed his father intellectually and who, for this very reason, should be that much more successful at enriching his kingdoms.

The Ohio State University 


\section{Bibliography}

Austin, J. L. How to Do Things with Words. Edited by J. O. Urmson and Marina Sbisà. London: Oxford University Press, 1962.

Belmartino, Susana M. "Estructura de la familia y 'Edades sociales' en la aristocracia de León y Castilla según las fuentes literarias e historiográficas (siglos X-XIII)." Cuadernos de historia de España 47-48 (1968): 256-328.

Brocato, Linde M. "Alfonso X's Libro de ajedrez e dados e tablas or Libro de los juegos Interrogating Convivencia." In Revisiting Convivencia in Medieval and Early Modern Iberia, edited by Connie L. Scarborough, 297-333. Newark, Del.: Juan de la Cuesta, 2014.

Burke, James F. "Alfonso X and the Structuring of Spanish History." Revista Canadiense de Estudios Hispánicos 9, no. 3 (Spring 1985): 464-71.

Burnett, C. S. F. "A Group of Arabic-Latin Translators Working in Northern Spain in the Mid-12th Century." The Journal of the Royal Asiatic Society of Great Britain and Ireland 1 (1977): 62-108. https://doi.org/10.1017/S0035869X00154644

Burrow, J. A. The Ages of Man: A Study in Medieval Writing and Thought. Oxford: Clarendon Press, 1986.

Cárdenas, Anthony J. "The Myth of Hercules in the Works of Alfonso X: Narration in the Estoria de España and in the General estoria." Bulletin of Hispanic Studies 74, no. 1 (January 1997): 5-20.

Cochelin, Isabelle. "Introduction: Pre-Thirteenth-Century Definitions of the Life Cycle." In Medieval Life Cycles: Continuity and Change, International Medieval Research 18, edited by Isabelle Cochelin and Karen Smyth. Turnhout: Brepols, 2013. 1-54.

Conde, Juan Carlos. "Las siete edades del mundo de Pablo de Santa María y su significación ideológica." In Modelos intelectuales, nuevos textos y nuevos lectores en el siglo XV, directed by Pedro M. Cátedra, 61-95. Salamanca: Seminario de Estudios Medievales y Renacentistas (SEMYR), 2012.

Craddock, Jerry R. "El Setenario: última e inconclusa refundición alfonsina de la primera Partida." Anuario de historia del derecho español 56 (1986): 441-66. 
Deyermond, Alan. "Written by the Victors: Technique and Ideology in Official Historiography in Verse in Late-Medieval Spain.” In The Medieval Chronicle VI, edited by Erik Kooper, 59-89. Amsterdam \& New York: Rodopi, 2009.

Doubleday, Simon R. The Wise King: A Christian Prince, Muslim Spain, and the Birth of the Renaissance. New York: Basic Books, 2015.

Duby, Georges. "Dans la France du Nord-Ouest au XII ${ }^{\text {ème }}$ siècle: les 'jeunes' dans la société aristocratique." Annales E.S.C. 19, no. 5 (Sept.-Oct 1964): 835-46.

Fernández-Ordóñez, Inés. "El taller historiográfico alfonsí. La Estoria de España y la General estoria en el marco de las obras promovidas por Alfonso el Sabio." In Scriptorium alfonsí: de los libros de astrología a las "Cantigas de Santa María," edited by Jesús Montoya Martínez and Ana Domínguez Rodríguez, 105-26. Madrid: Fundación Universidad Complutense, 1999.

Fierro, Maribel. "Alfonso X 'The Wise': The Last Almohad Caliph?" Medieval Encounters 15 (2009): 175-98. https://doi.org/10.1163/157006709X458819

Golladay, Sonja Musser. "Los libros de acedrex dados e tablas: Historical, Artistic and Metaphysical Dimensions of Alfonso X's Book of Games." Ph.D. diss. The University of Arizona, 2007.

Gómez Redondo, Fernando. Historia de la prosa medieval castellana. Vol. 1. Madrid: Cátedra, 1998.

Goodich, Michael E. From Birth to Old Age: The Human Life Cycle in Medieval Thought, 1250-1350. Lanham, Md.: University Press of America, 1989.

Haskins, Charles Homer. The Renaissance of the Twelfth Century. Cambridge: Harvard University Press, 1927.

Hawkes, Kristen. "Human Longevity: The Grandmother Effect." Nature 428, no. 6979 (2004): 128-29. https://doi.org/10.1038/428128a

Lapesa, Rafael. "Símbolos y palabras en el Setenario de Alfonso X." Nueva Revista de Filología Hispánica 29, no. 2 (1980): 247-61.

Márquez Villanueva, Francisco. El concepto cultural alfonsí: edición revisada y aumentada. Barcelona: Ediciones Bellaterra, 2004.

Martínez, H. Salvador. Alfonso X, El Sabio: Una biografía. Madrid: Ediciones Polifemo, 2003. 
Menocal, María Rosa. "To Create an Empire: Adab and the Invention of Castilian Culture." The Maghreb Review 31, no. 3-4 (2006): 194202.

Oeppen, Jim, and James W. Vaupel. "Broken Limits to Life Expectancy." Science 296, no. 5570 (2002): 1029-31. https://doi.org/10.1126/science.1069675

Olshansky, S. Jay, Bruce A. Carnes, and Aline Désesquelles. "Prospects for Human Longevity." Science 291, no. 5508 (2001): 1491-92. https://doi.org/10.1126/science.291.5508.1491

Palafóx, Eloísa. Las éticas del exemplum. Los Castigos del rey don Sancho IV, El Conde Lucanor y el Libro de buen amor. México, D. F.: Universidad Autónoma de México, 1998.

Pérez López, José Luis. "Los prólogos del Libro de las leyes y el fragmento llamado Setenario en la obra jurídica alfonsí." Revista de literatura medieval 14, no. 1 (2002): 109-43.

Rodríguez-Velasco, Jesús de. "La urgente presencia de Las Siete Partidas." La Corónica 38, no. 2 (Spring 2010): 99-135.

Roth, Norman. "Jewish Collaborators in Alfonso's Scientific Works." In Emperor of Culture: Alfonso X the Learned of Castile and His Thirteenth-Century Renaissance, edited by Robert I. Burns, 59-71. Philadelphia: University of Pennsylvania Press, 1990.

Salem, Sema'an I., and Alok Kumar, ed. and trans. Science in the Medieval World: "Book of the Categories of Nations" by Şā'id al Andalusī. Austin: University of Texas Press, 1991.

Sears, Elizabeth. The Ages of Man: Medieval Interpretations of the Life Cycle. Princeton: Princeton University Press, 1986.

Vanderford, Kenneth H., ed. Setenario. Buenos Aires: Instituto de Filología, 1945.

Wacks, David A. Framing Iberia: Maqamat and Frametale Narratives in Medieval Spain. Medieval and Early Modern Iberian World, vol. 33. Leiden and Boston: Brill, 2007. https://doi.org/10.1163/ej.9789004158283.i-279

Youngs, Deborah. "Adulthood in Medieval Europe: The Prime of Life or Midlife Crisis?" In Medieval Life Cycles: Continuity and Change, edited by Isabelle Cochelin and Karen Smyth, 239-64. Turnhout: Brepols, 2013. https://doi.org/10.1484/M.IMR-EB.1.100787 
—. The Life Cycle in Western Europe, c. 1300-c. 1500. Manchester, UK: Manchester University Press, 2006.

Zeitler, Jessica Katherine. "Intellectual Cartographic Spaces: Alfonso X, the Wise and the Foundation of the Studium Generale of Seville." Ph.D. diss., University of Arizona, 2013. 